\title{
KNOWLEDGE OF FUNCTIONAL FOODS BY CONSUMERS
}

\author{
Tímea Balogh ${ }^{1 *}$, Irén Köszegi ${ }^{2}$, Edit Hoyk ${ }^{3}$ \\ ${ }^{1}$ student, Faculty of Horticulture and Rural Development, John von Neumann University, Hungary \\ 2Department of Agroecomony and Rural Development, Faculty of Horticulture and Rural Development, John \\ von Neumann University, Hungary \\ ${ }^{3}$ Department of Agroecomony and Rural Development, Faculty of Horticulture and Rural Development, John \\ von Neumann University, Hungary \\ Great Plain Research Department, Institute for Regional Studies, Centre for Economic and Regional Studies, \\ Hungary \\ https://doi.org/10.47833/2020.2.AGR.030
}

\section{Keywords:}

functional foods

conventional foods

primary research

\section{Article history: \\ Received 5 May 2020 \\ Revised 28 April 2020 \\ Accepted 1 June 2020}

\begin{abstract}
Our research topic is current because of the fact that one of the main issues in human food consumption in Hungary today is the proper nutrition of people, or "you are what you eat". In our work, we compare conventional foods with functional foods in terms of consumer awareness. We chose these two food types which can be produced in different ways because we investigate what is the opinion of consumers based on their different sexes, ages, and quality of life. We examine what is their feeling about conventional and functional foods, how well they know them.
\end{abstract}

\section{Introduction}

Our research topic is current because of the fact that one of the main issues in human food consumption in Hungary today is the proper nutrition of people, or „you are what you eat". In our work, we compare conventional foods with functional foods in terms of consumer awareness. We chose these two food types which can be produced in different ways because we investigate what is the opinion of consumers based on their different sexes, ages, and quality of life. We examine what is their feeling about conventional and functional foods, how well they know them.

\section{Literature review}

\section{The difference between the concepts of conventional and functional food}

Nutrition is the totality of processes during which the human body uses food for the functioning, maintenance and growth of life [1]. Nutrition plays a major role in a person's life, which is tied to cultural values, social life, and identity [2]. The intake of nutrients into our body is vital for maintaining our functioning, and at the same time it means energy intake for us [3]. The essential key to this is the availability of food [4]. In Hungary, in addition to the production of conventional foods, the production of functional foods is also becoming more important, as there is a growing interest in so-called functional foods, hoping that these products are guaranteed to be healthier than conventionally produced products.

Those foods are so called conventional, in which various chemicals - pesticides and fertilizers - have been used during their production. By conventional we mean products and foods that have not been produced in an organic way. In another approach, the word "conventional" has a traditional and customary meaning. In contrast, functional foods are free from all of these. However,

\footnotetext{
* Corresponding author. E-mail address: baloghtimea1122@gmail.com
} 
the only positive argument is that products from conventional agriculture are cheaper than functional products [5].

\section{The role of functional foods in health-conscious nutrition}

Hungary has rather poor health indicators. One of the main reasons for the development of these indicators is unhealthy lifestyle, such as malnutrition [6]. Improper eating habits play a significant role in the development of civilization diseases. The results of discoveries and research in recent years confirm that nutrition has great importance in human health, so health-conscious nutrition is gaining prominence. In addition, it is a proven fact that proper nutrition can have a beneficial physiological effect on the human body [7]. Health-conscious consumers are paying more and more attention to what foods and what functional ingredients they bring into their bodies. Healthconscious consumers will be less accepting of substances found to be artificial. So consumer behaviour is changing. The health of our society could be improved and many of the civilization diseases and most deaths could be prevented, and the chances of their occurrence could be reduced by proper and healthy nutrition, in which functional foods play an essential role in the near future. This category of food meets the expectations of consumers regarding food, on the one hand, and protects the health of the individual in the long run, on the other hand [8]. Functional foods have disease-preventing and health-protective properties, so they have nutritional biological properties. They are natural foods that positively affect one or more vital functions in the body, thereby preventing or reducing the development of disease [9].

\section{Material and methods}

\subsection{Material}

Functional food is a relatively new interpretation, the wording of which, as well as the food industry qualification and procedural regulations, are related to Japan. The concept of functional food first appeared in Japan in the 1930s, and till nowadays there is no uniformly accepted definition, as it is difficult for experts to define this food category, both abroad and domestically. In addition, the available sources are very different, resulting in different wordings. The role of this food category can be traced back to the 1980s, when the Ministry of Health and Welfare of Japan initiated the regulation of foods with such health benefits in order to improve the public health situation. However, it first appeared in trade only in the 1990s, and since then its sales volume has been increasing [10]. In Japan, there is a special name for functional foods, which is as follows; "Foods with specific health benefits" [11].

\subsection{Methods}

We used a computer-based survey method to conduct our research. A total of 168 questionnaires were completed. The survey began on 12 September 2019 and ended on 10 October 24. The survey was conducted among domestic consumers, which cannot be considered representative, but it can give a collective picture of how consumers perceive functional foods and healthy - health-conscious - nutrition. Respectively, whether consumers know the difference between functional and conventional foods and what difference they notice between them. 


\section{Results}

In our research, we surveyed whether respondents are aware of the concept of foods from conventional production on the one hand, functional foods on the other, and who are the ones who regularly buy such foods.

Based on the respondents' answers, the identification of conventional food was effective in just over half. One answer was: „Conventional food means 'traditional', produced by industrial production", while the other: "Conventional food means those food which have been produced by backyard production". Nearly $55 \%$ of respondents were able to answer this question correctly. The two choices may have been misleading for those with little information about these products (Fig. 1.). Respondents' answers revealed that many identify the concept of conventional food with a product from backyard production and this can be observed in all age groups (Fig. 2.), as people usually do not associate the "traditional" label with industrial production, but associate it with a more natural production process.

$45,2 \%$
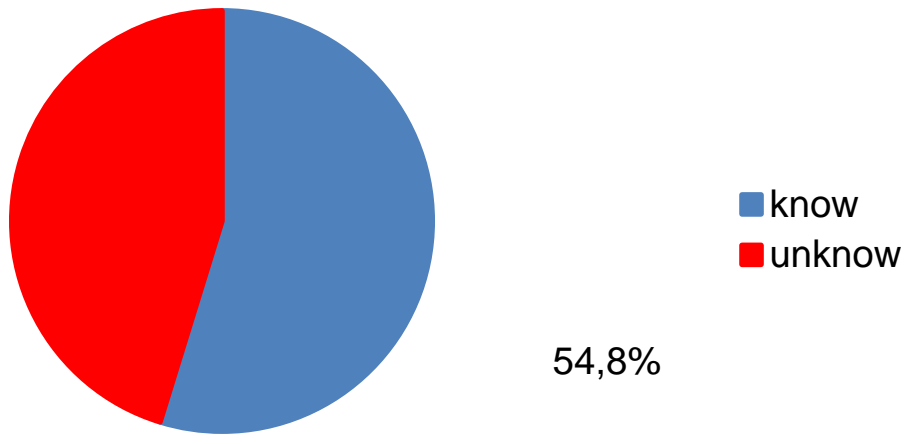

$54,8 \%$

Figure 1.: Respondents' knowledge about the definition of conventional food ( $\mathrm{N}=168)$

Source: Own survey, 2019. 


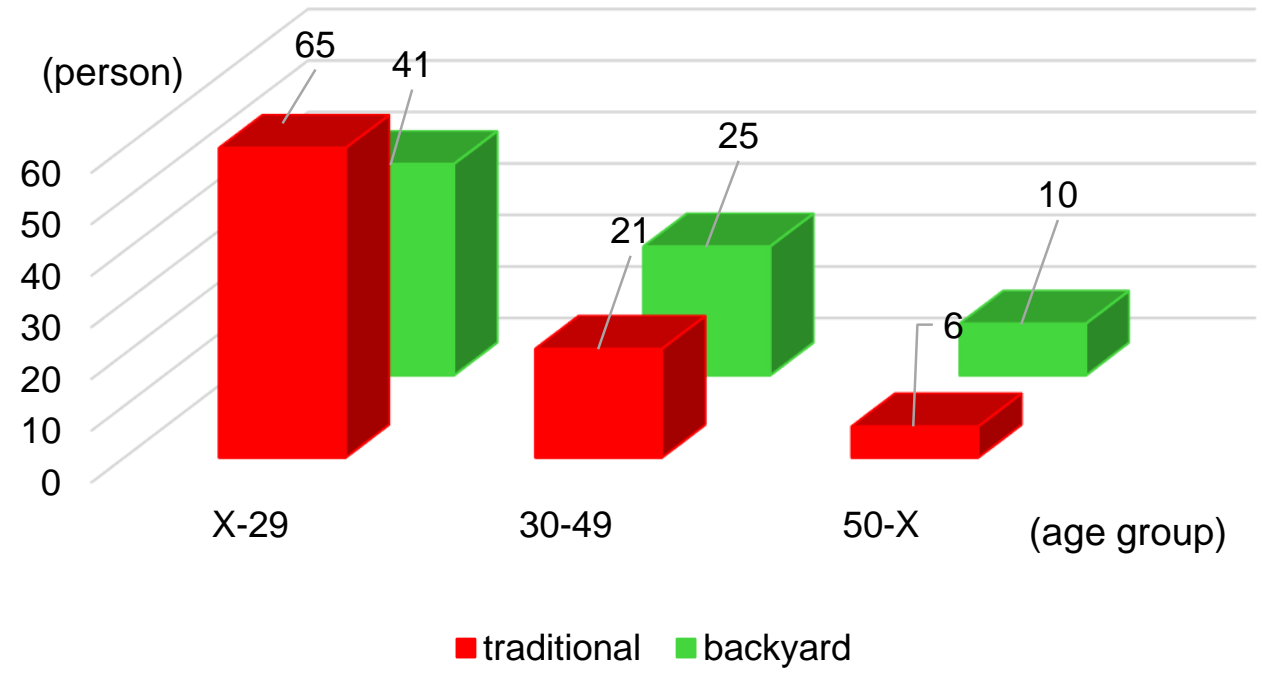

Figure 2.: Respondents' knowledge of the definition about conventional food by age distribution

Source: Own survey, 2019.

$90 \%$ of the respondents were aware of the concept of a functional food, which is „Foods that have a detectable positive effect on one or more vital functions in the body". The incorrect answer was „Functional foods are organicfoods”. High amount of correct answer may be due to the growing demand for healthy foods, which made the respondents more informed, or at least made it easier for them to narrow down the question asked. All of this will be seen later, where they demonstrate their knowledge by answering questions about functional foods (Fig. 3.). The choice of the correct definition was mainly made by respondents aged 20-29. In terms of profession, a higher proportion of students, both mental and physical, defined the definition of functional food well, so knowledge of the definition is not related to profession.

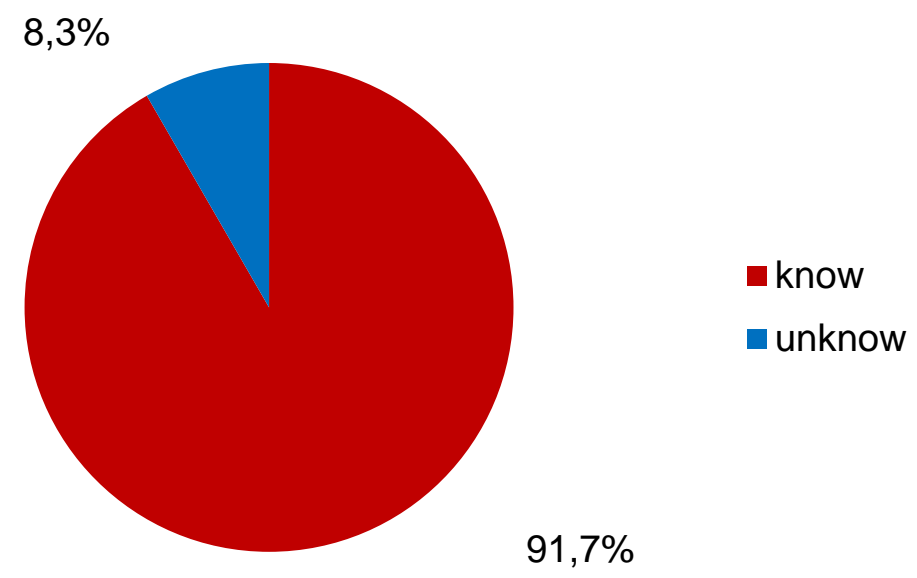

Figure 3.: Respondents' knowledge about the definition of functional food ( $N=168)$

Source: Own survey, 2019.

Figure 4. shows that respondents typically buy functional foods $(94.5 \%)$ and the number of those who do not do it is negligible. Most of the mentally respondents would be willing to buy such food again, because during mental work their bodies are not burdened by increased physical 
exertion, which they try to compensate by consuming functional foods. The majority of manual workers would also buy such products again, as they would like to replace the minerals used during physical exercise and increase their amount in order for them to be in good condition. Students, like those doing mental work, would buy functional food again for the same reason. Students (especially in higher education) are subject to increased mental strain at certain intervals, so it is advisable to consume such products in order to achieve adequate mental performance. Among retired respondents, only positive response was received. Most likely, the consumption of functional foods is associated with a healthy lifestyle and health maintenance. An aging organization produces more moderately the resources it needs for the body, which they seek to replace from other sources. For the aforementioned occupational categories, the rate of negative responses was negligible, which may be due to their unwillingness or inability to pay a higher price for these foods.

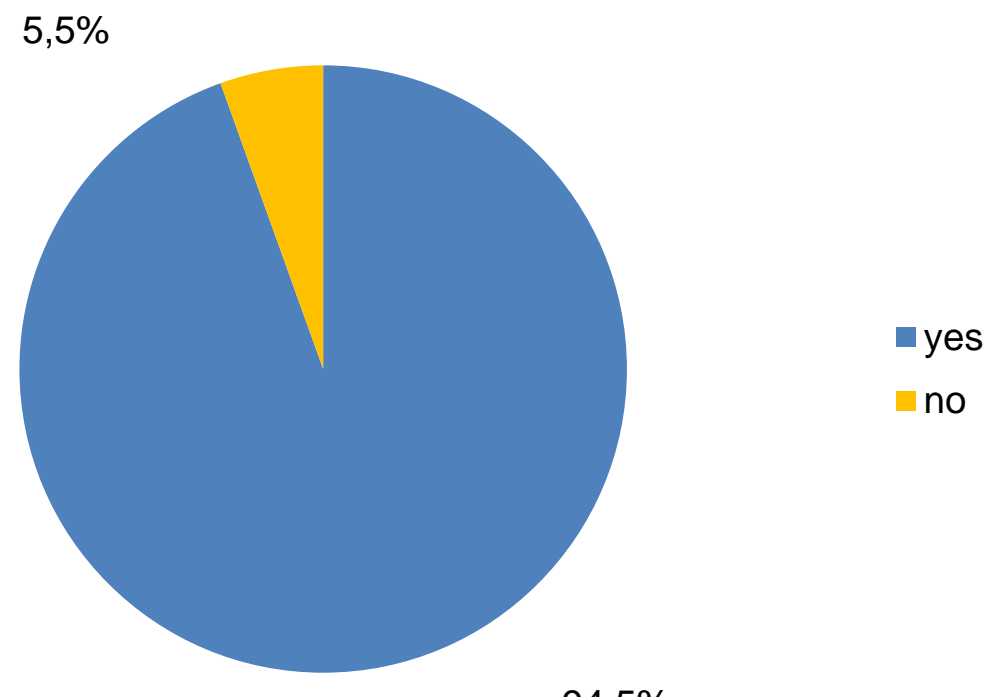

Figure 4.: Willingness of respondents to buy functional foods $(\mathrm{N}=164)$

Source: Own survey, 2019.

\section{Conclusions, suggestions}

As a result of our survey based on voluntary respondents, it can be concluded that some consumers are not aware of the concept about conventional foods and the underlying content of the concept. At the same time, the concept of functional food has already been correctly marked by respondents. It can be stated that functional foods are enjoying increasing popularity. Many prefer quality when choosing products, but price still plays a dominant role in purchasing decisions, and therefore many are unable, or only partially, to incorporate healthier foods into their diets due to their limited financial situation. The growing popularity of functional foods can be explained by the strengthening of health awareness.

\section{Acknowledgment}

This research is supported by EFOP-3.6.1-16-2016-00006 "The development and enhancement of the research potential at John von Neumann University" project. The Project is supported by the Hungarian Government and co-financed by the European Social Fund. 


\section{References}

[1] LAJOS A. (2005): Az egészségtudatosság sajátos vonásai a 14-18 éves korosztályban, külön tekintettel az élelmiszerfogyasztásra, Doktori (PHD) - értekezés, Szent István Egyetem, Gödöllö. pp. 11-20.

[2] https://szie.hu/file/tti/archivum/Lajos Attila ertekezes.pdf

[3] NAGY B. (2017): Hogyan befolyásolja a kultúra az egészséget II. rész, Táplálkozás, kultúra és egészség, Egészségfejlesztés, Vol. 58, No. 2. pp. 42-46.

[4] SZABÓ P. B. (2012): Élelmiszerek és az egészséges táplálkozás, Szegedi Tudományegyetem, Élelmiszerbiztonság és gasztronómia vonatkozású egyetemi együttműködés. pp. 7- 76.

[5] ANDRÁSFALVY B. - BALASSA I. - ÉGETÖ M. - GRÁFIK I. - GUNDA B. - KOTICS J. - PALÁDI K. A. PETERCSÁK T. (1997): Magyar Néprajz, Educatio Társadalmi Szolgáltató Nonprofit Kft.

[6] biokultura.org

[7] FÜLÖP N. - SZAKÁLY Z. (2007): Középiskolások táplálkozási szokásainak elemzése-primer piackutatás, Élelmiszer, Táplálkozás és Marketing, Vol. 4, No. 1. pp. 1-6.

[8] PANYOR Á. (2007): A különleges élelmiszerek piacnövelési lehetőségei megkérdezések tükrében, Doktori (PHD) értekezés, Corvinus Egyetem, Budapest. p. 4.

[9] SZAKÁLY Z. (2008): Trendek és tendenciák a funkcionális élelmiszerek piacán: Mit vár el a hazai fogyasztó, Élelmiszer, Táplálkozás és Marketing, Vol. 5, No. 2-3. pp. 7-9.

[10] DIPLOCK A. T. (szerk.) (1999): Scientific Concepst of Functional Foods in Europe, Consensus Document, Britisch Journal of Nutrition, Vol. 81, pp. 1-27.

[11] BíRÓ GY. (2003): Funkcionális élelmiszerek, természetes antioxidánsok szerepe az egészségmegőrzésben, Élelmezési ipar, Vol. 57, No. 4. pp. 117-123. 